\title{
Influence of scheduling in clinical dental care on indicators of oral health
}

\author{
Indicadores de saúde bucal como instrumento na organização da demanda ${ }^{1}$
}

Gabriela Christiel Soto ROJAS²

Fabiana de Lima VAZQUEZ ${ }^{2}$

Jaqueline Vilela BULGARELI²

Marcelo de Castro MENEGHIM ${ }^{2}$

Antonio Carlos PEREIRA ${ }^{2}$

\section{ABSTRACT}

\section{Objective}

Assess the oral health indicators in the Family Health Units (Unidades de Saúde da Familia - USFs) with scheduled demand in comparison with Family Health Units with spontaneous demand in oral health care, in Piracicaba.

\section{Methods}

10 Family Health Units located in Piracicaba, were randomly chosen: 5 Units with spontaneous demand and 5 Units with scheduled demand. Secondary data in daily production spreadsheets were collected from the information system, from February to September 2013. These were organized into indicators: 1) access; 2) resolutivity; 3) ratio of dental emergency per inhabitant; 4) mean number of individual preventive and curative dental procedures; 5) ratio of dental extraction per dental procedure; 6) ratio of dental extraction per inhabitant; 7) mean number of supervised toothbrushing sessions. Data were compared and statistically analyzed with the BioStat 5.0 program, by applying the Student's-t test $(p \leq 0.05)$.

\section{Results}

There were significant differences in the indicators of dental emergency, dental extraction per clinical procedure, and dental extractions per inhabitant, and these values were higher in Family Health Units with spontaneous demand.

\section{Conclusion}

The model of scheduling the demand for dental care adopted by the USFs interferes in the number of users seeking dental emergency treatments and reasons for extractions.

Termos de indexação: Dental health services. Health services accessibility. Health status indicators.

\section{RESUMO}

\section{Objetivo}

Analisar a influência de dois modelos de organização do atendimento odontológico clínico em indicadores de saúde bucal para as Equipes de Saúde Bucal.

\section{Métodos}

Dez Unidades de Saúde da Família (USF) localizadas em Piracicaba foram escolhidas aleatoriamente. Cinco Unidades com modelo de demanda espontânea e 5 Unidades com modelo de demanda organizada em Saúde Bucal. Dados secundários da produção odontológica ambulatorial foram coletados a partir do sistema de informação, de fevereiro a setembro de 2013. Depois foram organizados em indicadores: a) acesso; b) resolutividade; c) razão de urgência odontológica; d) procedimentos clínicos individuais preventivos e curativos e) razão de exodontias por procedimentos clínicos individuais preventivos e curativos f) razão de exodontias por habitante g) média de escovação dental supervisionada. Os dados foram comparados e analisados estatisticamente através do BioStat 5.0 através da aplicação do teste t de Student $(p \leq 0,05)$.

\section{Resultados}

Houve diferenças significativas nos indicadores de razão de urgências, razão de exodontia por procedimentos clínicos e razão de exodontias por habitante, sendo estes valores maiores no modelo da demanda espontânea.

\section{Conclusão}

O modelo de organização da demanda odontológica adotado pelas Equipes de Saúde Bucal interfere na procura de urgências odontológicas e razão de exodontias.

Termos de indexação: Serviços de saúde bucal. Acesso aos serviços de saúde. Indicadores básicos de saúde.

\footnotetext{
${ }^{1}$ Artigo baseado na dissertação de ROJAS GCS, intitulada "Indicadores de saúde bucal em função da organização da demanda: análise baseada no sistema de informação". Universidade Estadual de Campinas; 2014, p. 74 f.

${ }^{2}$ Universidade Estadual de Campinas, Faculdade de Odontologia, Departamento de Odontologia Social. Av. Limeira, 901, Areião, 13414-900, Piracicaba, SP, Brasil. Correspondência para / Correspondence to: AC PEREIRA. E-mail: <apereiral11@gmail.com>.
} 


\section{INTRODUCTION}

The definition of access involves multiple concepts, ranging from those focused on use of services, affordability, geographic area, socio-organizational and cultural factors, even concepts focused on users' subjectivity and perception of health their needs ${ }^{1}$.

In order to characterize the oral health practices and evaluate the effectiveness of clinical dental care scheduling in this study, access is considered the user's entry into the system and use of health services.

From this perspective, national oral health studies, such as the National Household Sample Survey (Pesquisa Nacional por Amostra de Domicilios - PNAD) 2003 and 2008 , showed that $15.7 \%$ and $11.7 \%$ of the population, respectively, have never been to the dentist, and the results of epidemiological survey SB Brazil in 2010, showed that $18 \%$ of adolescents, $7 \%$ of adults and $14 \%$ of seniors reported never having made a first dental appointment ${ }^{3}$.

Despite efforts made by means of health policies and programs, disadvantaged populations still find it difficult to gain access to dental services. Organization of the demand and clinical dental care scheduling could facilitate or interfere with patient access to healthcare ${ }^{4}$. The model of oral health care at the primary care level can be characterized as the organized demand and scheduling of appointments according to criteria of risk classification of users, or it can be characterized as spontaneous demand, when users seek dental treatment without previously making appointments or subject to risk classification ${ }^{5}$.

To quantify the access and use of services, the procedures performed by Oral Health Teams should be recorded in the health information system ${ }^{6}$, by means of data organized according to indicators, in order to assess the activities, or the degree of risk of an event or harm to health. In addition, this system enables to attribute value to data or aspects of reality that need to be known, and thus plan activities to achieve goals ${ }^{6-7}$. In this study the following indicators were those established by the Ministry of Health8: access, resolutivity, ratio of dental emergency per inhabitant, mean number of individual preventive and curative dental procedures, ratio of dental extraction per inhabitant, ratio of dental extraction per dental procedure, mean number of supervised toothbrushing sessions.

For the supervised toothbrushing indicator, the Piracicaba municipality goal for the period 2014-2017, was to increase the percentage of action from 3.9 to $4.0 \%{ }^{9}$. For the ratio of dental extraction per individual procedure, the goal was to reduce the percentage of this indicator from $7.2 \%$ to $7.0 \%$.

With reference to the indicator mean number of supervised toothbrushing sessions, the municipality achieved a percentage of 3.85 in 20136; as regards to the ratio of extraction per clinical procedure, the figure was $5.96 \%{ }^{6}$.

In Brazil, in 2012 the percentage of supervised toothbrushing sessions was 2.38; and the proportion of dental extractions per dental procedure was $9.28^{6}$.

The Health Care Information Systems that provide oral health information are the Ambulatory Care Information Systems (Sistema de Informação Ambulatorial - SIA) and the Primary Care Information System (Sistema de Informação da Atenção Básica - SIAB).

It is important to systematically monitor the results every month in order to guide the planning of activities and evaluate the organization of oral health care in the municipalities so that the goals can be achieved ${ }^{10}$.

From this perspective, the aim of the present study was to assess the oral health indicators in the Family Health Units (Unidades de Saúde da Família - USFs) with scheduled demand in comparison with Family Health Units with spontaneous demand in oral health care, in Piracicaba, in the period from February to September 2013.

\section{METHODS}

This was a cross-sectional, exploratory and descriptive study, developed in Piracicaba, which has an area of $1378.501 \mathrm{~km}^{2}$, and 388,412 inhabitants, grouped into 62 suburbs $^{9}$. Oral Health Teams (Equipe de Saúde Bucal - ESB) are divided among 17 Basic Health Units (Unidade Básica de Saúde -UBS), 17 Family Health Units, 2 Dental Specialty Centers (Centro de Especialidades Oodontologicas - CEO), 1 Prompt Dental Care Unit (Pronto Atendimento Odontologico - PAO).

The USFs included in the study, are organized in two different models of oral health care: scheduled demand and spontaneous demand for oral health care. The sample was randomly selected by lottery, and the only inclusion criterion was having Oral Health Team included in the USF. Therefore, 5 USFs characterized by scheduled demand and 5 USF characterized by spontaneous demand were chosen.

In the USFs working with the spontaneous demand model in oral health, all dentists perform a workload of 40 hours per week and have a statutory contract with the Municipality of Piracicaba. In these units, the dental 
appointment times are flexible, and dentists are available to perform treatments the same day users seek the USF, either due to a real need for care, clinical complaint, or even without any symptoms. The vast majority of patients have a dental appointment, as requested, and 6-7 vacancies are available per period, in addition to the vacancies reserved for emergency dental treatment.

In USFs working with the scheduled demand model for oral health, professionals perform a workload of 20 hours and there are 2 dentists in each of these USF. All USFs open at 07:00h and work through to 17:00h from Monday to Friday. In these units, the dental care schedule is organized considering the classification of households according to risk criteria, using the Coelho scale, categorizing them as risk $0,1,2$ or 3 . This classification was based on the analysis of the records $A$ of the SIAB which were filled out by Community Health Agents (Agente Comunitario de Saúde - ACS) on their first visit to the families.

After the results obtained by the classification of families, treatment began with families identified as 3 then 2 and ultimately families risk 1 . Users were scheduled as often as necessary until the full treatment is completed. One or two family members were scheduled to receive complete treatment. On conclusion of treatment of these members, other family members were called, to finalize treatment of the whole family. Therefore, user access occurred by scheduled demand, according to the time of the appointment, with 6-7 vacancies being made available per period.

In all USFs dental emergencies are treated during the first hours of each period.

To analyze the oral health care models by means of oral health indicators, secondary data of each of the 10 USFs selected were collected from the SIA and SIAB systems, from February to September 2013. These data were obtained through the Oral Health Coordinators of the Municipal Secretary of Health. The indicators collected were as follows: a) access: showed the percentage of persons who had access to a first dental appointment in the year, for the purpose of diagnosis and development of a preventive-therapeutic plan ${ }^{11}$; b) resolutivity: evaluated whether the team maintains a good ratio between the number of completed treatments (TC) and the number of first dental appointments scheduled (access); c) ratio of dental emergency per inhabitant: evaluated the ability of prevention of emergency cases by means of regular scheduled service. Helped with planning, so that staff could assess the demand for dental urgency and organize their work process to increase collective and individual preventive actions scheduled ${ }^{11} ;$ d) mean number of individual preventive and curative dental procedures: consisted of the number of basic dental clinical and / or surgical procedures performed per individual, in the population resident in a particular place and period; e) ratio of dental extractions to the number of procedures: this indicator could reveal the lack of access by the population to dental services, generating an accumulated demand for extractions; $f$ ) ratio of dental extractions per inhabitant: this indicator referred to the number of extractions per 100 persons; g) mean number of supervised toothbrushing sessions: expressed the percentage of coverage of the mean number of persons who had access to toothbrushing and topical fluoridated dentifrice, with guidance from a health professional, considering the year, place and period of the activity ${ }^{12}$.

For analysis and comparison of the indicators among the selected USFs, we used the Student's- $t$ test at a $5 \%$ level of significance. The Bioestat 5.0 program was used to analyze the data.

\section{RESULTS}

Table 1 shows the ratio of access, resolutivity and ratio of dental emergencies per inhabitant between the USFs with scheduled demand and USFs with spontaneous demand for oral health. With regard to access, both care models were found to offer service to new patients, with no significant differences among the USFs surveyed. Thus, in USFs with scheduled demand, for every 100 patients treated, five gained access to initial treatment; and in USFs with spontaneous demand, nine out of every 100 patients treated had access to a first scheduled dental appointment.

The ratio of resolutivity, which expresses the conclusion of dental treatment that was started, should ideally be equal to 1, i.e., every patient who started treatment concluded the it. Therefore, among the USFs compared, there were no significant differences in this indicator, however, in the USFs with the scheduled demand value was greater than 1 (2.07), meaning that there were more treatments concluded than treatments started. Whereas, in the USFs with spontaneous demand, resolutivity was 0.74 which means more treatments started in comparison with those completed.

As regards the reason for dental emergencies, there was a statistically significant difference $(p<0.05)$ between the USFs working with scheduled demand and 
spontaneous demand, indicating that the ratio of dental emergency per inhabitant were higher in USFs working with spontaneous demand, which can be interpreted as approximately 2 emergencies per 100 persons in USFs with the scheduled demand model, and about 4 dental emergencies per 100 people in the group of USFs working with spontaneous demand.

Table 1. Access, resolutivity and dental emergency per inhabitant, between USF with scheduled demand and USF with spontaneous demand, Piracicaba, 2013.

\begin{tabular}{lccc}
\hline Variables & USF & USF & \\
\cline { 2 - 3 } & $\begin{array}{c}\text { Scheduled } \\
\text { Demand }\end{array}$ & $\begin{array}{c}\text { Spontaneous } \\
\text { Demand }\end{array}$ & p-value \\
\hline & Mean (sd) & Mean (sd) & \\
$\begin{array}{l}\text { Access (1st dental } \\
\text { appointment/100inhabitants) }\end{array}$ & $4,95(3,07)$ & $8.76(3.20)$ & $0.091 \mathrm{~ns}$ \\
$\begin{array}{l}\text { Resolutivity (TC/1st dental } \\
\text { appointment) }\end{array}$ & $2.07(1.76)$ & $0.74(0.13)$ & $0.167 \mathrm{~ns}$ \\
$\begin{array}{l}\text { Dental emergencies per } \\
\text { inhabitant }\end{array}$ & $1.81(0.66)$ & $3.62(1.02)$ & 0.010 * \\
\hline
\end{tabular}

\#Student's-t test; * Significant $(p \leq 0.05)$; ns not significant $(p>0.05)$

In regard to the type of dental procedure, there were significant differences in ratio of dental extraction per inhabitant, which was higher for USFs working with the spontaneous demand model, which means they performed 4 extractions per 100 persons. However, in the USFs with scheduled demand this result was 1 extraction per 100 persons. Significant differences were also found in the ratio of dental extraction per dental procedure, showing 6 extractions per 100 dental procedures for units with spontaneous demand and 2 extractions per 100 dental procedures in other USFs. There were no statistical differences between USFs, compared with the average of individual preventive and curative dental procedures (Table 2).

Table 2. Extractions and dental procedures in USFs with scheduled demand compared with USFs with spontaneous demand, Piracicaba, 2013.

\begin{tabular}{|c|c|c|c|}
\hline \multirow[t]{2}{*}{ Variables } & USF & USF & \multirow[b]{2}{*}{$p$-value } \\
\hline & $\begin{array}{l}\text { Scheduled } \\
\text { Demand }\end{array}$ & $\begin{array}{l}\text { Spontaneous } \\
\text { Demand }\end{array}$ & \\
\hline & Mean (sd) & Mean ( sd) & \\
\hline $\begin{array}{l}\text { Dental extraction per } \\
\text { inhabitant }\end{array}$ & $\begin{array}{c}0.01 \\
(0.008)\end{array}$ & $0.04(0.015)$ & 0.005 * \\
\hline $\begin{array}{l}\text { Dental extraction per } \\
\text { dental procedure }\end{array}$ & $\begin{array}{c}0.02 \\
(0.013)\end{array}$ & $0.06(0.036)$ & 0.043 * \\
\hline
\end{tabular}

\# Student's-t test; * Significant $(p \leq 0.05)$; ns not significant $(p>0.05)$.
Table 3 shows the mean number of supervised toothbrushing sessions. When comparing USFs working with spontaneous demand and USFs working with scheduled demand, no significant differences were found between the models of care. Therefore, in the USFs with spontaneous demand about 3.5 out of every 100 persons gained access to these procedures, and in the USFs with scheduled demand, 3.02 out of every 100 people participated in collective preventive procedures, had access to fluoride and the opportunity to consolidate the toothbrushing habit.

Table 3. Supervised toothbrushing in USFs with scheduled demand compared with USFs with spontaneous demand, Piracicaba, 2013.

\begin{tabular}{lccc}
\hline Variables & USF & USF & p-value \\
\cline { 2 - 3 } & $\begin{array}{c}\text { Scheduled } \\
\text { Demand }\end{array}$ & $\begin{array}{c}\text { Spontaneous } \\
\text { Demand }\end{array}$ & \\
\hline & Mean (sd) & Mean (sd) & \\
Supervised toothbrushing & $3.02(2.578)$ & $3.49(3.205)$ & $0.806 n s$ \\
\hline
\end{tabular}

\# Student's-t test; * Significant $(p \leq 0.05)$; ns not significant ( $p>0.05)$.

\section{DISCUSSION}

This study presents data on the importance of evaluating oral health services. The National Oral Health Policy proposes greater access to primary care, because historically, oral health in Brazil was of a mutilating nature and prioritized children and pregnant women. An alternative to change this situation would be an organized flow chart of dental care, enabling greater and equitable access, focused on the real needs of users, looking at knowledge derived through experience or observation of the determinants of health and disease.

The oral health care model should be focused on organized offer of actions and health services, with results expected in progressive change in the forms of organization and production of health actions exclusively directed to spontaneous demand ${ }^{7}$. The National Policy Primary Care (Política Nacional de Atenção Básica - PNAB) also recommends planning, programming and implementation of health care activities in accordance with the population's needs, with priority given to clinical and health interventions in health problems according to criteria of frequency, risk, vulnerability and resilience. This PNAB recommends division of the schedule according to criteria of health problems, life cycles, sex and diseases must be avoided, because it makes it difficult for users to access the service ${ }^{10}$. 
The search for alternatives to overcome the models of care with spontaneous demand, are being implemented in several municipalities, such as, for example the municipality of Belo Horizonte, has established a protocol for the management of spontaneous demand in all health services. This municipality argues that this type of demand will always exist, and there are several ways to address this; risk rating is a way to contribute to establishing the priority of car $^{13}$. Nevertheless, there are still some difficulties, often unfavorable, in the way of implementing models based on scheduled demand, as result of excess demand and difficulty of negotiating the priority of already scheduled prevention and promotion of actions with the population, because the public expects immediate care. Thus, despite implementation of the Oral Health Team in Family Health Units, many teams did not plan the organization of demand, as they are linked to fulfilling spontaneous demand and tied to a pent-up demand, with a predominance of restorative surgical care without realizing improvements in health conditions and access by the community ${ }^{14}$. This means that the mere implementation of an ESB does not guarantee improvements in access and care.

In the comparisons of the ratio of dental emergencies per inhabitant among the USFs, grouped according to the organization of demand, the USFs working with spontaneous demand showed a higher number of dental emergencies per inhabitant in comparison with USFs working with scheduled demand. A probable explanation for this result could be that the accumulated oral health needs are not being controlled. In addition, the ability to prevent cases of dental emergency was lower in the spontaneous demand model than in scheduled demand model, because in this type of scheduled demand tools are used to assess risk and early identification of future oral health needs.

The most frequent dental emergencies are predominantly of a non traumatic nature, among them acute pain due to pulpitis, periapical pathology, deep dental caries, pulp necrosis, periodontal abscess, facial cellulitis, pericoronitis and tooth fractures. The treatments most frequently performed are pulp chamber opening, temporary restoration, extraction and prescribing medications ${ }^{15}$. However, these diseases can be prevented or identified in the early stages, to avoid a larger number of dental emergencies in the near future, and consequently a higher demand for dental $\mathrm{care}^{16}$. The early diagnosis of diseases that cause dental emergencies leads to considerable benefits being achieved both in terms of perception of service quality and the cost-effectiveness ${ }^{17}$.
The demand for dental emergencies is related to the most vulnerable sectors of the population. This emphasizes the importance of using tools for family, individual and social risk classification to improve dental care in these sectors and prevent emergency situations ${ }^{18}$. Therefore access to primary care eases the burden of dental emergency provided the care of emergency in time and in an opportune manner is guaranteed ${ }^{19}$.

The study Fonseca et al. ${ }^{18}$, evaluating the demand for dental emergency in the Prompt Dental Care Unit, showed an increasing demand for this service, with dental extractions being the most prevalent procedures. Moreover, the patients who were attended in these services came from the most vulnerable areas, and were persons who could not be treated in primary care services ${ }^{18}$. The study of Fodor et al. ${ }^{20}$ also found that people classified as having poor economic resources, had the highest number of urgencies, leading to the view that the accumulated needs of this population could not be controlled and in time, because of the large demand. These studies showed the importance of, and the need to organize the demand for dental services, using socioeconomic risk assessment tools to accurately identify people who need to be treated with the highest priority and within the shortest time.

Pimentel et al. ${ }^{21}$, in their study of characterizing the work process of oral health services showed that for the type of dental appointment scheduling, many teams also mentioned making appointments according to spontaneous demand, especially in small municipalities in the state of Pernambuco, which reproduces a traditional health post model, a situation in which the patient only seeks the service when the disease is already established, and in the case of dentistry, when there is toothache.

In this study, access to dental treatment was measured by means of the indicator of scheduled first dental appointment per inhabitant. No inequalities were observed as regards access, which reflects that in both USF groups, persons had access to dental treatment in the oral health program developed by the team. However, this could be best explained by the fact the USFs with scheduled demand are in transition, as clearly seen in some units with high completed treatment / treatment started coefficients, which may have generated a measurement bias in the study.

With regard to resolutivity, the separate analysis of the variables first dental appointment and completed treatment, did not reflect an impact on the resolutivity, considering that even in the Family Health Unit with a high coefficient of access, resolutivity may be low, if the 
coefficient of completed treatments is low. Therefore, the analysis of the variable first dental appointment alone measures the level of access to dental treatment, but does not reflect the degree of resolutivity, in the same way as completed treatment analyzed separately, only reflects the completion of dental treatments.

In the group of USFs with scheduled demand, resolutivity coefficient indicated that treatments were being concluded without new treatments being started. The opposite happens with the USFs with spontaneous demand where the resolutivity coefficient indicated that the number of treatments completed was lower than the treatments started. However two problems affect the analysis of this variable: a) the USFs with scheduled demand were in transition; changing from a spontaneous demand to a scheduled demand; they had a high demand of treatment started, which increased the resolutivity, but decreased access and b) this transition did not occur in all the USFs with scheduled demand (some have already done this), which caused a variation in the data, with impact on the standard deviation measures and possibly hindering a more realistic analysis of what happened in terms of access and resolutivity.

Carvalho $^{22}$ pointed out that the impact of oral health actions in the Family Health Strategy shows clear progress in universality, fairness and integrity. This analysis is important in assessing the outcomes of primary attention considering that comprehensive care is realized in the coordination of care with Primary Health Care, integrated into the network of other levels of care ranging from access (first visit), monitoring and resolution (completed treatment) of the existent health need.

When analyzing the groups of procedures performed by Oral Health Team in the USFs, there was an association between spontaneous demand and a higher coefficient of extractions per dental procedures. The higher coefficient probably indicated the burden of disease at an advanced stage, for which no other therapeutic possibilities are offered. There was also a higher ratio of dental extractions per inhabitants in USFs with spontaneous demand, which refers to mutilating treatment in oral health care, as opposed to offering conservative and preventive procedures, which does take into account the importance of developing actions that cover promotion and prevention in the different cycles of life, so that the need for dental extractions will be lower in the future.

The value obtained by the Oral Health Teams in the indicator of extraction per dental procedure, in comparison with the targets set by the municipality
$(7 \%)^{9}$, are values that are within the established limits, therefore, the USFs with scheduled demand and USFs with spontaneous demand have a low percentage of extractions in comparison with individual preventive and curative dental procedures with reference to municipal goals. However, USFs with spontaneous demand are above mean of Ratio of dental extractions to the dental procedures at the municipal level $(5.96 \%)^{6}$ obtained in 2013. All teams recorded values below the value of the indicator at the national level $(9.28 \%)^{6}$ obtained in 2012.

The study of Silva et al..$^{23}$ analyzed the results of the indicator of individual extractions per dental procedures, in the period 2001-2010, and showed a reduction from $22.2 \%$ to $17.5 \%$ in this indicator. In addition, they noted that the number of extractions had been stable over the period and that the reduction of this indicator was not attributed to the reduction in the number of extractions, but to the increase in conservative oral health procedures. From this aspect, the implementation of preventive and conservative procedures prevents an increase in the number of future extractions.

No inequalities between the USFs were observed in the indicator of individual preventive and curative dental procedures. This indicator shows the repercussion of this group of oral health practices on preventing mutilation, represented by extractions, and is related to access to dental services. Nevertheless, once again caveat the variation found between the different USF, the fact that it increased the standard deviation and prevented a better analysis of these variables.

With reference to the indicator of the mean number of supervised toothbrushing obtained by USFs with scheduled demand and USFs with spontaneous demand, the values are close to the value of the indicator at municipal level $(3.85 \%)^{6}$ obtained in 2013 , and above the value obtained at the national level in $2012(2.98 \%)^{6}$. Nevertheless, further efforts are required to expand access to these health activities (schools, community centers, therapeutic communities) in order to achieve the goals established at the municipal level, i.e., to increase the percentage of collective action from 3.9 to 4.0 percent of supervised toothbrushing ${ }^{9}$. The search for resolution of the oral health needs with individual basic curative and dental procedures should not allow a decrease in preventive and health education actions, so that the oral health care model does not become a curative model only, but rather a health surveillance model.

There is a need to organize to demand that reconciles both the scheduled demand and spontaneous demand, 
because this spontaneous demand may be the expression of another way to perceive health needs, and this is not determined only by the morbidity profile; it may be associated with other reasons for seeking the health services.

\section{CONCLUSION}

We concluded that the model of organizing the demand in oral health services adopted in the USFs interferes in the demand for dental emergencies, and is higher for models based on spontaneous demand.

It is important to assess the structured oral health care models with the purpose of guiding the planning and implementation of actions at the local level, essential for constructing more resolvable public dentistry, with higher

\section{REFERENCES}

1. Sanchez RM, Ciconelli RM. Conceitos de acesso à saúde. Rev Panam Salud Pública. 2012; 31(3):260-8. doi: 10.1590/S102049892012000300012

2. IBGE. Instituto Brasileiro de Geografia e Estatística [citado 2013 maio 10]. Disponível em: <http://www.ibge.gov.br/home/>.

3. Brasil. Ministerio de Saúde. Secretaria de Atenção à Saúde. Secretaria de Vigilância em Saúde. Projeto SB Brasil 2010. Pesquisa Nacional de Saúde Bucal: resultados principais. Brasilia: Ministério da Saúde; 2012 [citado 2013 maio 10]. Disponível em: <http://bvsms.saude.gov.br/bvs/publicacoes/pesquisa_ nacional_saude_bucal.pdf>.

4. Padilha WWN, Valencia AMG, Cavalcanti AL, Gomes LB, Almeida RVD, Taveira GS. Planejamento e programação odontológicos no Programa Saúde da Família do Estado da Paraíba: estudo qualitativo. Pesq Bras Odontoped Clin Integr. 2005;5(1):65-74.

5. Soares SS, Lima LD, Castro ALB. O papel da atenção básica no atendimento às urgências: um olhar sobre as políticas. J Manag Prim Health Care. 2014;5(2):170-7.

6. Brasil. Ministério da Saúde. Departamento de Informática do SUS-DATASUS. Informações de Saúde (BI) [citado 2014 Abr 22]. Disponível em: <http://www2.datasus.gov.br/DATASUS/index. php?area $=04>$

7. Brasil. Ministério da Saúde. Secretaria de Atenção à Saúde. Departamento de Atenção Básica. Coordenação Nacional de Saúde Bucal. Diretrizes da Política Nacional de Saúde Bucal [online]. Brasília: Ministério da Saúde; 2004 [citado 2014 Abr 22]. Disponível em: < http://189.28.128.100/dab/docs/publicacoes/ geral/diretrizes_da_politica_nacional_de_saude_bucal.pdf > .

8. Brasil. Ministerio da Saúde. Portaria $n^{\circ} 493$, de 10 de março de 2006. Aprova a Relação de Indicadores da Atenção Básica 2006, cujos indicadores deverão ser pactuados entre municípios, estados e Ministério da Saúde [online]. Diário Oficial da União, Brasília (DF); 2006 mar 10 [citado 2014 Abr 22]. Disponível em: efficiency and quality, to make materialize the principles of the Unified Health System for the population.

\section{Acknowledgements}

We fully appreciate the Coordination of Oral Health of Piracicaba Municipality for the valuable contributions in developing this research.

\section{Collaborators}

GCS ROJAS, FL VAZQUEZ, JV BULGARELI, MC MENEGHIM and AC PEREIRA participated in all stages of development of the article, in the conception, design, analysis, data interpretation and writing of the article.

<http://www.saude.mppr.mp.br/modules/conteudo/conteudo. php? conteudo $=49>$.

9. São Paulo (Estado). Secretaria Municipal de Saúde. Plano Municipal de Saúde, triênio 2014-2017. Piracicaba: Secretaria Municipal de Saúde; 2013.

10. Brasil. Ministério da Saúde. Secretaria de Atenção À Saúde. Departamento de Atenção Básica. Política Nacional de Atenção Básica [online]. Brasília: Ministério da Saúde; 2007 [citado 2014 Abr 22]. Disponível em: <http://189.28.128.100/dab/docs/ publicacoes/geral/pnab.pdf>.

11. Brasil. Ministerio de Saúde. Programa Nacional de Melhoria do Acesso e da Qualidade na Atenção Básica (PMAQ). Manual Instrutivo [online]. Brasília: Ministério da Saúde; 2012 [citado 2014 Abr 22]. Disponível em: <http://189.28.128.100/dab/docs/ publicacoes/geral/manual_instrutivo_pmaq_site.pdf >.

12. Brasil. Ministério da Saúde. Orientações acerca dos indicadores da pactuação de diretrizes, objetivos e metas 2012 conforme pactuação na reunião da comissão intergestores Tripartite de 26 de abril de 2012 [online]. Brasília: Ministério da Saúde; 2012 [citado 2014 Abr 22]. Disponível em: < http://www.saude.pi.gov.br/ uploads/warning_document/file/20/Instrutivo_Pacto_2013.pdf>

13. Belo Horizonte. Prefeitura Municipal. Secretaria Municipal de Saúde. Demanda espontânea na atenção primária à saúde em Belo Horizonte [online]. Belo Horizonte: Prefeitura Municipal; 2014 [citado 2014 Abr 23]. Disponível em: <http://portalpbh. pbh.gov.br/pbh/ecp/files.do? evento=download\&urlArqPlc=prot ocolo-demanda-espontanea.pdf>.

14. Barros SG, Chaves SCL. A utilização do Sistema de Informações Ambulatoriais (SIA-SUS) como instrumento para caracterização das ações de saúde bucal. Epidemiol Serv Saúde. 2003;12(1):4151. doi: 10.5123/S1679-49742003000100005

15. Munerato MC, Fiamenghi DL, Petry PC. Epidemiología de las urgencias odontológicas en niños atendidos en la Facultad de Odontología de la Universidad del Zulia. Ciencia Odontológica. 2008; 5(2): 134-144

16. Douglass $A B$, Douglass JM. Family practice residency program, middlesex Hospital. Am Fam Phys. 2003;67(3):511-6. 
17. Halling A, Ordell S. Unit of Community Dentistry, Centre for Public Health Sciences, Linköping, Sweden. Swed Dent J. 2000;24(5-6):173-81.

18. Fonseca DAV, Mialhe FL, Ambrosano GMB, Pereira AC, Meneghim MC. Influencia da organização da atencao basica e das caracteristicas sociodemograficas da população na demanda pelo pronto atendimento odontologico municipal. Ciênc Saúde Coletiva. 2014;19(1):269-77. doi: 10.1590/141381232014191.2048

19. Carret MLV, Fassa AG, Domingues MR. Inappropriate use of emergency services: a systematic review of prevalence and associated factors. Cad Saude Publica. 2009;25(1):7-28. doi: 10.1590/S0102-311X2009000100002

20. Fodor $A B$, Navarrete EF, Cáceres EC, Muñoz FT. Atención de Urgencia Odontológica en el Hospital de Urgencia Asistencia Pública. Rev Dental Chile. 2005;96(3):3-6.

21. Pimentel FC, Albuquerque PC, Martelli PJL, Souza WV, Acioli RML. Caracterização do processo de trabalho das equipes de saúde bucal em municípios de Pernambuco, Brasil, segundo porte populacional: da articulação comunitária à organização do atendimento clínico. Cad Saúde Pública. 2012;28(Supl):146-57. doi: 10.1590/S0102-311X2012001300015

22. Carvalho SR. As contradições da promoção à saúde em relação à produção de sujeitos e a mudança social. Ciênc saúde coletiva. 2004;9(3):669-78. doi: 10.1590/S1413-81232004000300018

23. Silva LS, Santana KR, Pinheiro HHC, Nascimento LS. Indicadores de atenção básica e especializada em saúde bucal nos municípios do Estado do Pará, Brasil: estudo ecológico, 20012010. Epidemiol Serv Saúde. 2013;22(2):325-34. doi: 10.5123/ S1679-49742013000200014 